\title{
Sensitive Detection of Molecular Targets in Cancer by Minisequencing
}

\author{
Şirin K. Yüksel' ${ }^{1}$ (D) , Cemaliye B. Akyerli² (iD
}

${ }^{1}$ Acıbadem Mehmet Ali Aydınlar Üniversitesi, Fen Edebiyat Fakültesi, Moleküler Biyoloji ve Genetik Bölümü, İstanbul, Türkiye

${ }^{2}$ Acıbadem Mehmet Ali Aydınlar Üniversitesi, Tıp Fakültesi, Tıbbi Biyoloji Anabilim Dalı, İstanbul, Türkiye

Şirin K. Yüksel, Öğr. Gör. Dr. Cemaliye B. Akyerli, Dr. Öğr. Üyesi

Correspondence: Cemaliye B. Akyerli Acıbadem Mehmet Ali Aydınlar Üniversitesi, Tıp Fakültesi, Tıbbi Biyoloji Anabilim Dalı, İstanbul, Türkiye

Phone:-

E-mail: cemaliye.boylu@acibadem.edu.tr

\section{ABSTRACT}

Purpose: Molecular alterations leading to specific mutations are essential for tumor development and survival. Accurate analysis of these molecular targets is important for diagnosis, early detection, forecasting of prognosis and aiding in the treatment of different cancer types. Therefore, for sensitive analysis of molecular markers, we aimed to optimize and use minisequencing protocols besides Sanger sequencing.

Methods and Materials: Sanger sequencing and minisequencing were performed for IDH1 R132, IDH2 R140/R172 and TERT promoter (228/C250 mutations using genomic DNA isolated from glioma samples. Minisequencing reactions were performed with detection primers using SnaPshot Multiplex Ready Reaction Mix and run on an automated capillary electrophoresis. Multiplex peaks were analyzed with GeneMapper Software.

Results: In the multiplex minisequencing analyses, peaks corresponding to wild type alleles and different mutations were detected. The presence of the peaks next to the wild type peaks points to the presence of variations in that location and the nature of the mutation can be identified according to the color.

Conclusions: Identification of molecular markers in cancer is very important. Minisequencing is a reliable method for the detection of molecular targets.

Keywords: IDH, minisequencing, molecular targets, mutations, TERT promoter

\section{Minidizileme ile kanserdeki moleküler hedeflerin hassas tayini}

ÖZET

Amaç: Belirli mutasyonlara neden olan moleküler değişiklikler tümör gelişimi ve sağkalımı için gereklidir. Bu moleküler hedeflerin doğru analiz edilmesi farkı kanser tiplerinde tanı, erken teşhis, prognoz tahmini ve tedavide yol gösterme açısından önemlidir. Bu nedenle, moleküler belirteçlerin hassas tayini için Sanger dizilemenin yanı sıra minidizileme protokolünü de optimize ederek kullanmayı amaçladık.

Yöntem: Gliom örneklerinden elde edilmiş genomik DNAlar kullanılarak IDH1 R132, IDH2 R140/R172 ve TERT promotör C228/C250 mutasyonları için Sanger dizileme ve minidizileme yapıılmıştır. Minidizileme reaksiyonları mutasyon saptama primerleri ile "SnaPshot Multiplex Ready Reaction Mix" kullanılarak gerçekleştirilmiş ve otomatik kapiler elektroforezinde yürütülmüştür. Çoklu eğriler "GeneMapper Software" kullanılarak analiz edilmiştir.

Bulgular: Minidizileme analizlerinde, yabanıl tip alellere ve farklı mutasyonlara ait eğriler tespit edilmiştir. Yabanıl tip piklerin yanında yer alan eğriler, o noktada varyasyona işaret etmekte ve mutasyon renge göre tanımlanmaktadır.

Sonuç: Moleküler belirteçlerin kanserde tayini oldukça önemlidir. Minidizileme yöntemi moleküler hedeflerin belirlenmesinde güvenilir bir yöntemdir.

Anahtar sözcükler: IDH, minidizileme, moleküler hedefler, mutasyonlar, TERT promotör 
C ancer is a group of diseases which involves the uncontrolled growth of abnormal cells. It has the potential to invade other tissues and also spread to different parts of the body. When cancer is considered at a cellular level, it is generally caused by the molecular alterations leading to specific mutations (1). Recent advances in molecular biology and genetics have provided us to study cancers with valuable prognostic and predictive significance. Many genetically altered molecular targets are described in cancer cells which are essential for tumor development and survival. There are many known molecular markers which allow early detection of different cancer types. These lead to a decrease in mortality rate. Furthermore, in some cases, targeted therapy of tumors and patient follow-up appear to be possible. Therefore, it is extremely important to study various molecular markers for diagnosis, prognosis and therapy in cancer patients (2).

Recently, isocitrate dehydrogenase (IDH1 and IDH2) and human telomerase reverse transcriptase (TERT) promoter mutations were detected in different cancer types. IDH1/2 mutations lead to the conversion of a-ketoglutarate (aKG) to D-2-hydroxyglutarate (D2HG) oncometabolite (3). Since the structure of D2HG is similar to aKG, the catalytic activity of aKG-dependent dioxygenases is inhibited, resulting in deregulation of histone modification and DNA demethylation (4). IDH mutations, predominantly IDH1 R132 and IDH2 R140/R172, were identified in a variety of myeloid malignancies and solid tumors (5).

Upregulation of telomerase activity by TERT promoter mutations enabling replicative immortality is a hallmark of cancer (6). De novo ETS binding site creating hotspot mutations in the TERT promoter, C228T (c.-124C>T, chr5: 1295228 C>T) and C250T (c.-146C>T, chr5:1295250 C>T), were reported to occur in melanomas and a few other tumors (7). These mutations were shown especially to be useful biomarkers for early detection of urinary and liver tumors and classification and prognostication of brain tumors, respectively (8).

Detection of IDH and TERT mutations in patient samples is useful for the diagnosis and prediction of prognosis in different cancer types. Sanger sequencing by automated capillary electrophoresis is regarded as the gold standard for variant detection. The limit of detection of Sanger analysis is $15-20 \%$ in cancer samples depending on the heterogeneity of tumors (9). Since the sensitivity of the analysis method is very important, we aimed to optimize a more sensitive method for the detection of hotspot IDH1/2 and TERT promoter mutations by minisequencing.

Minisequencing, also referred as primer extension, is a method used to determine the base immediately 3 ' to a detection primer by enzymatically extending the primer by one base only $(10,11)$. In this method, the absence of dNTPs and presence of 3 '-OH lacking chain-terminating 2',3'-dideoxynucleotide triphosphates (ddNTPs) ensures the termination of elongation after the incorporation of a single base. With the use of labeled ddNTPs, single nucleotide changes can be identified by automated capillary electrophoresis $(11,12)$. Up to twelve detection primers can be used simultaneously for multiplex mutation analysis by increasing the primer size with the addition of oligonucleotide tails (13).

In this context, it is very important to use sensitive methods for the analysis of molecular targets in order to avoid false results. Therefore, together with Sanger sequencing, our aim is to use and optimize minisequencing and also consider these methods for molecular marker detection.

\section{Materials and Methods}

\section{Genomic DNA isolation}

Genomic DNA was extracted from paraffin-embedded (FFPE-sections) or fresh frozen glioma tumor samples stored in liquid nitrogen by QIAamp DNA Mini Kit (Qiagen, USA) according to the manufacturer's instructions. Deparaffinization of FFPE-tissues was performed by xylene/ethanol before DNA isolation. The archival glioma tumor samples were kindly provided by Prof. Dr. Necmettin Pamir, Acibadem Mehmet Ali Aydinlar University Department of Neurosurgery.

\section{Product amplification and purification}

PCR amplifications were performed for the regions of IDH1 (NG_023319.2), IDH2 (NG_023302.1) and TERT (NG_009265.1) genes spanning the IDH1 R132, IDH2 R140 and R172, TERT promoter C228T and C250T mutations, respectively. Some primers were designed using Primer3web (v.4.1.0) software (http://primer3.ut.ee/) and the others were taken from the literature (Table 1). PCR was carried out in a total of $25 \mu \mathrm{l}$ reaction volume, consisting of 50-100 ng DNA, 1X Colorless GoTaq Flexi Buffer, 1.5 $\mathrm{mM} \mathrm{MgCl2,} 200 \mu \mathrm{M}$ dNTP, 1\% DMSO, 10 pmoles of each primer and 0.8 U GoTaq Flexi DNA polymerase (Promega, USA). Cycling conditions were an initial denaturing step at $96^{\circ} \mathrm{C}$ for $2 \mathrm{~min}$, followed by 35 cycles of denaturation at $95^{\circ} \mathrm{C}$ for $30 \mathrm{sec}$, annealing at $55-64^{\circ} \mathrm{C}$ for $35 \mathrm{sec}$, extension at $72^{\circ} \mathrm{C}$ for $45 \mathrm{sec}$, and a final extension at $72^{\circ} \mathrm{C}$ for $5 \mathrm{~min}$. All the amplicons were checked on $2 \%$ agarose gel. Then, $5 \mu \mathrm{l}$ of PCR product was purified with $2 \mu \mathrm{l}$ of the enzyme 
using ExoSAP-IT kit (Affymetrix, USA) according to the manufacturer's recommendations.

\section{Sanger sequencing}

$1 \mu \mathrm{l}$ of the purified amplicons was Sanger sequenced with 20 pmoles of forward and reverse primers (Table 1) using GenomeLab DTCS - Quick Start Kit (Beckman Coulter Life Sciences, USA). Cycle sequencing conditions were 25 cycles of denaturation at $96^{\circ} \mathrm{C}$ for $10 \mathrm{sec}$, annealing at $50^{\circ} \mathrm{C}$ for $5 \mathrm{sec}$, extension at $60^{\circ} \mathrm{C}$ for $4 \mathrm{~min}$. Sequence reactions were loaded on Beckman Coulter GeXP Genetic Analysis System (Beckman Coulter Life Sciences, USA) after dye removal by ethanol precipitation. Sequence analysis was performed by Lasergene SeqMan II, v5.08 (Dnastar Inc., Madison, USA). GenBank sequences NM_005896.4, NM_002168.4, NG_009265.1 were used as reference sequences for IDH1, IDH2 and TERT genes, respectively.

\section{Minisequencing}

Multiplex minisequencing analyses were performed in a total of $4 \mu \mathrm{l}$ reaction volumes with $1.5 \mu \mathrm{l}$ of the purified amplicons and 10 pmoles of specific detection primers for IDH1-R132G/S/C, IDH1-R132L/H/P, IDH2-R140Q/L, IDH2R140W, IDH2-R172K/M, IDH2-R172W, hTERT-C228T and hTERT-C250T mutations (Table 2) using $0.5 \mu$ l SnaPshot Multiplex Ready Reaction Mix (Applied Biosystems, USA). The colors of individual ddNTPs assigned by the manufacturer are: green $(A)$, black $(C)$, blue $(G)$, red $(T)$. Minisequencing conditions were 25 cycles of denaturation at $96^{\circ} \mathrm{C}$ for $10 \mathrm{sec}$, annealing at $50^{\circ} \mathrm{C}$ for $5 \mathrm{sec}$, extension at $60^{\circ} \mathrm{C}$ for $30 \mathrm{sec}$. Minisequencing reactions were run on Applied Biosystems 3130XL Genetic Analyzer (Applied Biosystems, USA) using $1.5 \mu \mathrm{l}$ sample in $9 \mu \mathrm{l} \mathrm{Hi}$ Di Formamide (Applied Biosystems, USA) and $1 \mu \mathrm{ILIZ-120}$ size marker (Applied Biosystems, USA). Multiplex peaks were analyzed with GeneMapper Software, version 5 (Applied Biosystems, USA).
Table 2. Detection primers used for the minisequencing analysis of IDH1 R132, IDH2 R140/R172, TERT promoter C228T and C250T mutations

\begin{tabular}{l|l|}
$\begin{array}{l}\text { Detection } \\
\text { primer }\end{array}$ & Primer sequence \\
\hline IDH1-R132G/S/C & TGGGTAAAACCTATCATCATAGGT \\
\hline IDH1-R132L/H/P & TTTTATGACTTACTTGATCCCCATAAGCATGA \\
\hline IDH2-R140Q/L & TGGAAAAGTCCCAATGGAACTATCC \\
\hline IDH2-R140W & TTTTTGTGGAAAAGTCCCAATGGAACTATC \\
\hline IDH2-R172K/M & TTTTTCCCTGGCTGGACCAAGCCCATCACCATTGGCA \\
\hline IDH2-R172W & TTTTTTTTTTTTCCCTGGCTGGACCAAGCCCATCACCATTGGC \\
\hline hTERT-C228T & GAGGGGCTGGGAGGGCCCGGA \\
\hline hTERT-C250T & TTTTCGCGGACCCCGCCCCGTCCCGACCCCT* \\
\hline $\begin{array}{l}\text { (*): Initially TERTp-C250T: 5'- CGCGGACCCCGCCCCGTCCCGACCCCT- 3' primer } \\
\text { was used for the detection of C250T mutation. Because the two peaks (for } \\
\text { C228 and C250) were not easily distinguished especially in heterozygous } \\
\text { samples, hTERT-C250T primer was designed and used. }\end{array}$
\end{tabular}

\section{Results}

Sanger sequencing analysis was performed for IDH1 R132, IDH2 R140 and R172, TERT promoter C228T and C250T mutations in glioma samples. A representative result of the Sanger sequencing analysis for IDH1-R132H mutation is shown in Figure 1.

In the initial experiments, various annealing temperatures $\left(55-64^{\circ} \mathrm{C}\right)$ were tried to achieve optimum PCR amplifications. In the minisequencing analysis, in order to confirm that the detection primers are working, first of all, each of them was studied alone and then the reactions were multiplexed.

Multiplex minisequencing analyses were performed with mutation specific primers in three separate reactions. Since almost all IDH and TERT mutations are heterozygous in glioma $(8,14)$, peaks corresponding to wild type must be detected in the analysis.

\begin{tabular}{|c|c|c|c|c|}
\hline Primer name & Primer sequence & Product size (bp) & Annealing $\left({ }^{\circ} \mathrm{C}\right)$ & Analysis method \\
\hline $\mathrm{IDH} 1 \mathrm{fc} *$ & ACCAAATGGCACCATACGA & \multirow{2}{*}{254} & \multirow{2}{*}{60} & \multirow{2}{*}{ Sanger sequencing } \\
\hline $\mathrm{IDH} 1 \mathrm{rc}^{*}$ & TTCATACCTTGCTTAATGGGTGT & & & \\
\hline IDH1-Exon4-1F & ACCAAGGATGCTGCAGAAGCTAT & \multirow{2}{*}{363} & \multirow{2}{*}{55} & \multirow{2}{*}{ Minisequencing } \\
\hline IDH1-Exon4-2R & TACCTTGCTTAATGGGTGTAGATACCA & & & \\
\hline IDH2-Exon4-1F & CTGTCCTCACAGAGTTCAAGCTGAAG & \multirow{2}{*}{207} & \multirow{2}{*}{55} & \multirow{2}{*}{$\begin{array}{c}\text { Sanger sequencing \& } \\
\text { minisequencing }\end{array}$} \\
\hline IDH2-Exon4-2R & CAGGTCAGTGGATCCCCTCTCCA & & & \\
\hline TERT-F** & GGCCGATTCGACCTCTCT & \multirow{2}{*}{489} & \multirow{2}{*}{61} & \multirow{2}{*}{ Sanger sequencing } \\
\hline TERT-R** & AGCACCTCGCGGTAGTGG & & & \\
\hline TERT-PRMT-3F & GCGGAAAGGAAGGGGAGGGGCT & \multirow{2}{*}{112} & \multirow{2}{*}{64} & \multirow{2}{*}{ Minisequencing } \\
\hline TERT-PRMT-4R & СTTCACCTTCCCAGCTCCGCCTCCT & & & \\
\hline
\end{tabular}


Any other peak next to these peaks implies the presence of mutations in that location and can be identified depending on the color of the peak, according to the manufacturer's instructions. The colors of the wild type and mutant peaks are given in Table 3. Minisequencing analysis results of IDH1 R132H, IDH2 R172K and TERTC250T mutations are given in Figure 2, 3 and 4, respectively.

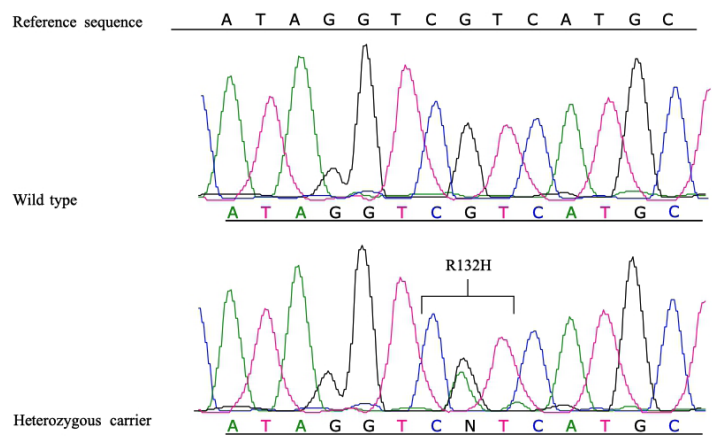

Figure 1: Sanger sequencing analysis of an IDH1 R132H heterozygous patient sample. The gray line is the reference sequence (GenBank NM_005896.4). The bracket on the electropherogram shows the heterozygous $\mathrm{R} 132 \mathrm{H}$ variation (lower line) compared with the homozygous wild type sample (upper line).

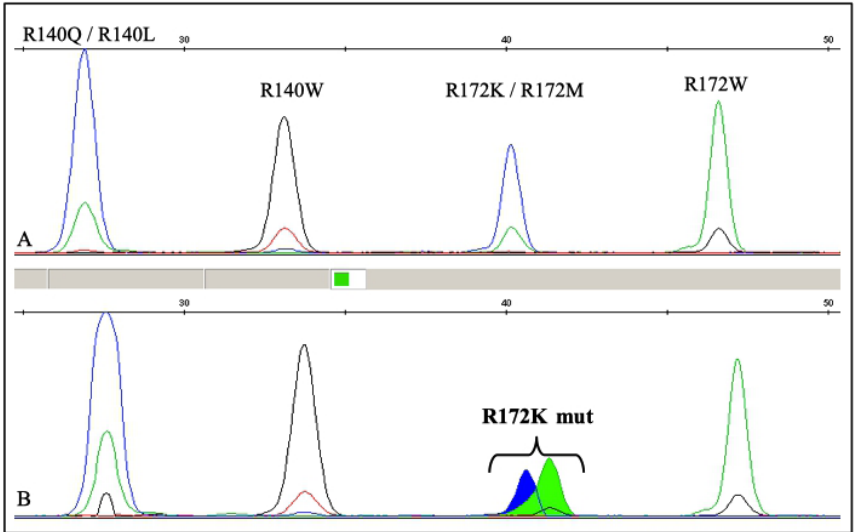

Figure 3: Minisequencing analysis of an IDH2 R172K heterozygous patient sample. A) Four wild type peaks correspond to IDH2-R140Q/L (blue), IDH2R140W (black), IDH2-R172K/M (blue), IDH2-R172W (green), respectively. B) The green peak next to the third peak (second blue) indicates a heterozygous R172K mutation.

In our study, mutation results of minisequencing analysis perfectly overlapped with Sanger sequencing, whereas approximately $1 \%$ of the samples tested negative with Sanger sequencing were found to be positive with minisequencing. Immunohistochemistry (IHC) is also a powerful technique used for the diagnosis of the diseases, such as cancers. We have also performed some preliminary experiments on samples that were found to be IDH negative by IHC and were able to detect IDH mutations by minisequencing as well.
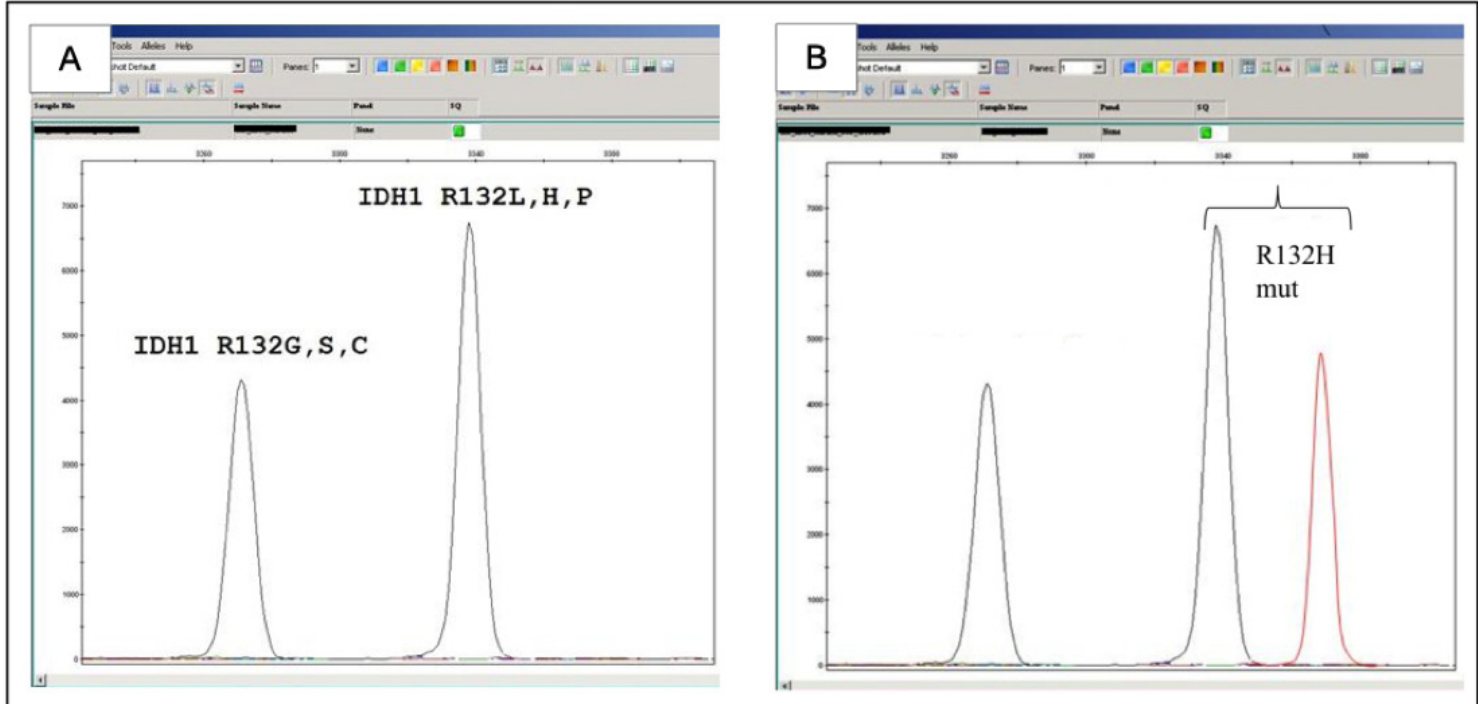

Figure 2: Minisequencing analysis of an IDH1 R132H heterozygous patient sample. A) The two peaks correspond to wild type IDH1-R132G/S/C and IDH1-R132L/H/P, respectively. B) The red peak next to the second peak points to the heterozygous $\mathrm{R} 132 \mathrm{H}$ mutation. 


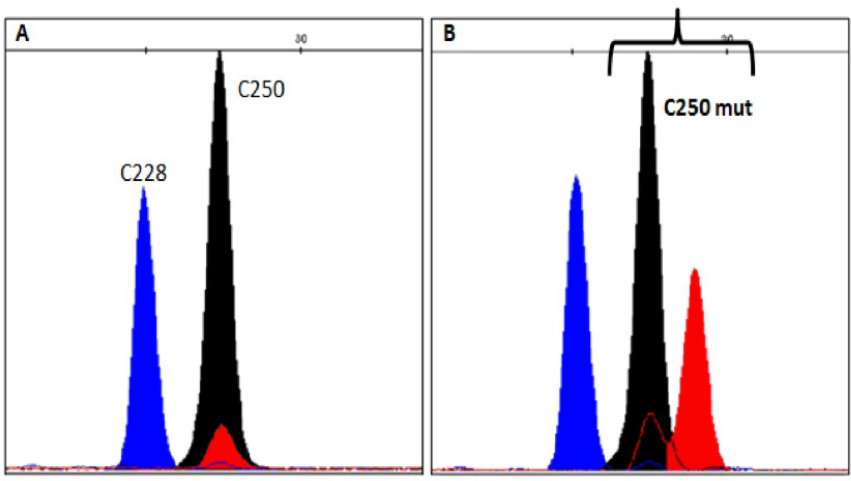

Figure 4: Minisequencing analysis of a TERT promoter C250T heterozygous patient sample. A) The blue and black peaks correspond to wild type TERT promoter C228 and C250, respectively. B) The red peak next to the black peak points to the heterozygous $\mathrm{C} 250 \mathrm{~T}$ mutation.

Table 3. Properties of detected mutations and peaks in minisequencing analysis

\begin{tabular}{|c|c|c|c|}
\hline Detection primer & $\begin{array}{c}\text { Nucleotide } \\
\text { change }\end{array}$ & $\begin{array}{c}\text { Wild type peak } \\
\text { color }\end{array}$ & $\begin{array}{c}\text { Mutant peak } \\
\text { color }\end{array}$ \\
\hline IDH1-R132G/S/C & R132G (C>G) & Black & Blue \\
\hline IDH1-R132G/S/C & R132S (C>A) & Black & Green \\
\hline IDH1-R132G/S/C & R132C (C>T) & Black & Red \\
\hline IDH1-R132L/H/P & R132L (G>T) & Black & Green \\
\hline IDH1-R132L/H/P & R132H (G>A) & Black & Red \\
\hline IDH1-R132L/H/P & R132P (G>C) & Black & Blue \\
\hline IDH2-R140Q/L & R140Q (G>A) & Blue & Green \\
\hline IDH2-R140Q/L & R140L (G>T) & Blue & Red \\
\hline IDH2-R140W & R140W (C>T) & Black & Red \\
\hline IDH2-R172K/M & R172K (G>A) & Blue & Green \\
\hline IDH2-R172K/M & R172M (G>T) & Blue & Red \\
\hline IDH2-R172W & R172W (A>T) & Green & Red \\
\hline hTERT-C228T & $\mathrm{C}>\mathrm{T}$ & Green & Green \\
\hline hTERT-C250T & $\mathrm{C}>\mathrm{T}$ & Red & Red \\
\hline
\end{tabular}

\section{Discussion}

Molecular markers, which are the genetic signatures of alterations in gene sequences, expression levels and protein structures or functions, are very important in carcinogenesis. Their detection in different types of cancer is reported to be helpful for diagnosis, detection of early development, and aiding in treatment (2). With the advances in molecular biology, many techniques evolved for the detection of molecular markers. The golden standard, Sanger sequencing, was developed by Frederick Sanger and colleagues in 1977, as a chain-termination method based on the selective incorporation of ddNTPs $(15,16)$. In this method, minute amounts of ddNTPs are added to the dNTP containing reactions, leading to random termination of polymerase-mediated elongation resulting in a cocktail of extension products. However, there are still drawbacks of this method as the limit of detection and heterogeneity testing.

Testing in heterogenous tumors is very challenging. For more sensitive results, it is better to use higher percent tumor samples, tumor sorting or single-cell sequencing; however, it is not possible for every patient and/or cancer type. The development of next generation technologies in the last decade targeted at solving these problems using very high coverages; however, they are very expensive. Taking these factors into consideration, minisequencing is more favorable, being a simple, inexpensive and more sensitive method that can be used for the multiplex detection of cancer biomarkers.

Due to the fact that glioma tumors are very heterogenous and the sensitivity of Sanger sequencing is approximately $15-20 \%$ (9), difficulties were encountered in the analysis of molecular markers, especially in low percent tumor samples. Therefore, we have optimized minisequencing protocols and used multiplex primers for IDH1 R132, IDH2 R140/ R172 and TERT promoter C228 and C250 mutations.

Preliminary experiments were performed at different annealing temperatures and PCR conditions to get clear amplifications. As minisequencing is a primer-driven reaction, clear PCR amplifications and post-PCR purification are essential to avoid background noise. Some problems were encountered especially in the multiplexing of reactions, for example, a longer detection primer for TERT promoter C250T mutation was designed to better distinguish the two mutations in the heterozygous samples (Table 2). After the optimizations, the studied mutations were successfully identified by minisequencing analysis.

Being a fluorescence-based DNA mutation analysis protocol, minisequencing is a sensitive and reliable method, which is easily applicable especially for the detection of low amount samples (17). Accurate analysis and data interpretation may easily be performed with the aid of automated capillary electrophoresis and computer assisted visualization of mutations. One of the main benefits is that with the use of labelled ddNTPs, there is no need for labelled detection primers, making the procedure inexpensive and easily applied. Multiplex analysis may be achieved by only extending the detection primers with the addition of nucleotide tails, which leads to short turnaround times in routine clinical testing. 
In conclusion, for more accuracy, it is better to evaluate the status of molecular markers taking the result of various techniques into consideration, like immunohistochemistry, Sanger sequencing and minisequencing. Primer extension is a promising principle for mutation detection and genotyping. Our study is very important for the evaluation of the reliability of minisequencing.

Acknowledgements: Minisequencing protocol has been optimized and used in the projects (grant number 112-S149 and 214-S-097) supported by TÜBITAK (Scientific and Technological Research Council of Turkey).

\section{REFERENCES}

1. Chakravarthi BV, Nepal S, Varambally S. Genomic and Epigenomic Alterations in Cancer. Am J Pathol 2016;186(7):1724-35.

2. Nair M, Sandhu SS, Sharma AK. Cancer molecular markers: A guide to cancer detection and management. Semin Cancer Biol 2018;52(Pt 1):39-55.

3. Dang L, White DW, Gross S, Bennett BD, Bittinger MA, Driggers EM, et al. Cancer- associated IDH1 mutations produce 2-hydroxyglutarate. Nature 2009;462(7274):739-44.

4. Xu W, Yang H, Liu Y, Yang Y, Wang P, Kim SH, et al. Oncometabolite 2-hydroxyglutarate is a competitive inhibitor of alpha-ketoglutaratedependent dioxygenases. Cancer Cell 2011;19(1):17- 30.

5. Waitkus MS, Diplas BH, Yan H. Biological Role and Therapeutic Potential of IDH Mutations in Cancer. Cancer Cell 2018;34(2):186-195.

6. Hanahan D, Weinberg RA. The hallmarks of cancer. Cell 2000;100(1):57-70.

7. Vinagre J, Almeida A, Pópulo H, Batista R, Lyra J, Pinto V, et al. Frequency of TERT promoter mutations in human cancers. Nat Commun 2013;4:2185.

8. Killela PJ, Reitman ZJ, Jiao Y, Bettegowda C, Agrawal N, Diaz LA, et al. TERT promoter mutations occur frequently in gliomas and a subset of tumors derived from cells with low rates of self-renewal. Proc Natl Acad Sci USA 2013;110(15):6021-6.

9. Tsiatis AC, Norris-Kirby A, Rich RG, Hafez MJ, Gocke CD, Eshleman $J R$, et al. Comparison of Sanger sequencing, pyrosequencing, and melting curve analysis for the detection of KRAS mutations. J Mol Diagn 2010;12(4):425-432.

10. Syvänen AC, Aalto-Setälä K, Harju L, Kontula K, Söderlund H. A primer-guided nucleotide incorporation assay in the genotyping of apolipoprotein E. Genomics 1990;8(4):684-92.

11. Syvänen AC. From gels to chips: "minisequencing" primer extension for analysis of point mutations and single nucleotide polymorphisms. Hum Mutat 1999;13(1):1-10.

12. Pastinen $T$, Kurg A, Metspalu A, Peltonen $L$, Syvänen AC. Minisequencing: a specific tool for DNA analysis and diagnostics on oligonucleotide arrays. Genome Res 1997;7(6):606-14.

13. Carvalho CMB, Pena SDJ. Optimization of a multiplex minisequencing protocol for population studies and medical genetics. Genet Mol Res 2005;4 (2):115-125.

14. Balss J, Meyer J, Mueller W, Korshunov A, Hartmann C, von Deimling A. Analysis of the IDH1 codon 132 mutation in brain tumors. Acta Neuropathol 2008;116(6):597-602.

15. Sanger $F$, Coulson AR. A rapid method for determining sequences in DNA by primed synthesis with DNA polymerase. J Mol Biol 1975;94(3):441-8.
16. Sanger F, Nicklen S, Coulson AR. DNA sequencing with chainterminating inhibitors. Proc Natl Acad Sci USA 1977;74(12): 5463-5467.

17. Fiorentino F, Magli MC, Podini D, Ferraretti AP, Nuccitelli A, Vitale $\mathrm{N}$, et al. The minisequencing method: an alternative strategy for preimplantation genetic diagnosis of single gene disorders. Mol Hum Reprod 2003;9(7):399-410. 